International Journal of Agriculture and Environmental Research

ISSN: 2455-6939

Volume: 06, Issue: 06 "November-December 2020"

\title{
EFFICIENCY OF DIFFERENT HERBICIDES IN THE CONTROL OF Digitaria insularis L. IN COFFEE CROP
}

\author{
Gabriel Andrade Muniz ${ }^{1}$, Kleso Silva Franco Júnior ${ }^{2}$, Giselle Prado Brigante ${ }^{3}$ \\ ${ }^{1}$ Agronomy student, Department of Agronomy, Centro Superior de Ensino e Pesquisa (CESEP), \\ Av. Dr. Ataíde Pereira de Souza, 730 - Centro, Machado - MG, 37750-000. \\ ${ }^{2,3}$ Agronomic engineer, Department of Agronomy, Centro Superior de Ensino e Pesquisa (CESEP), \\ Av. Dr. Ataíde Pereira de Souza, 730 - Centro, Machado - MG, 37750-000. \\ DOI: https://doi.org/10.51193/IJAER.2020.6605
}

\begin{abstract}
Among the main species of weeds in coffee growing, we highlight the Digitaria insularis L., which is increasingly difficult to control, as it has a large number of seeds, high power of dissemination and high germination rate, which may have been some of the factors that contributed to the species showing resistance to some herbicides. The objective of this research was to evaluate the efficiency of different herbicides, in the control of Digitaria insularis L. in coffee plantations, being carried out in a plantation of approximately 4 years, variety Catuaí Vermelho IAC 144, experimental design in randomized blocks (DBC), containing 5 treatments and 4 repetitions, totaling 20 experimental plots. The treatments were: Roundup Original (Glyphosate $445 \mathrm{~g} / \mathrm{L}$ ), Select (Cletodim $240 \mathrm{~g} / \mathrm{L}+$ vegetable oil $930 \mathrm{~g} / \mathrm{L}$ ), Verdict $\mathrm{R}$ (Haloxifope-P-methyl 124,7 g/L + vegetable oil 930 g/L), Fusilade (Fluazipofe-P-butyl 250 g/L) and Control (without the addition of herbicides). The percentage of death of the Digitaria insularis L. was made visually at 7, 15 and 30 DAA, where $0 \%$ represented absence of damage and $100 \%$ complete death of the plant. It is concluded that the use of Cletodim $240 \mathrm{~g} / \mathrm{L}$ (Select) and Haloxifope-p-Butyl 124,7 g/L (Verdict R), associated with vegetable oil $930 \mathrm{~g} / \mathrm{L}$ in the dosage of $0,5 \%$ of the syrup, were the best treatments among those used in this research to control the Digitaria insularis L.
\end{abstract}

Keywords: Coffee, Matology, Weeds, Resistance.

\section{INTRODUCTION}

Brazil is the largest producer and exporter of coffee in the world, so coffee growing has great economic prominence (FAPEMIG, 2018), generating thousands of direct and indirect jobs in the 
International Journal of Agriculture and Environmental Research

ISSN: 2455-6939

Volume: 06, Issue: 06 "November-December 2020"

country every year. Being represented by more than 100 species, especially $C$. arabica and $C$. canephora. And according to (CONAB, 2019) in a total area of 2,28 million hectares, with 5,66 billion coffee trees in production and training. In this context, the State of Minas is highlighted as being the main coffee hub in the country, responsible for about $51 \%$ of the national coffee production (IBGE, 2016), and responsible for 62\% of exports in 2015 (more than 20 million bags) (MDIC, 2016).

Currently, approximately 2,16 million hectares are grown with coffee (arabica and canephora), where 319,72 thousand hectares $(14.8 \%)$ are crops in the formation stage and 1,84 million hectares $(85,2 \%)$ are crops in full production $(\mathrm{CONAB}, 2019)$, which shows the growth and development of coffee culture throughout the country each year.

Digitaria insularis L., due to its great resistance, its high dissemination power, large number of seeds and height between 50 and $100 \mathrm{~cm}$ (KISSMANN and GROTH, 1997), make it difficult to control it in coffee plantations, making it even greater the dispute for nutrients, water and light with coffee crops, causing a reduction of nutrients in the leaves and affecting growth and reduced productivity (RONCHI et al., 2003; FIALHO et al., 2011).

Chemical control through the use of several herbicides, is being increasingly used, obtaining better results in the control of weeds, so success depends frankly on a correct application technology, on the equipment, with the calibration and use of tips correct. Essentially contributing to hit the target thus avoiding drift, and damage to the culture. (LORENZI, 2014).

Glyphosate [N- (phosphonomethyl) glycine], a non-selective, post-emergent and systemic active ingredient, which is absorbed through the leaves, translocating through the phloem to all locations to the meristematic regions where they are responsible for plant growth. This herbicide acts on the various enzymatic systems, specifically inhibiting the enzyme 5enolpyruvilshikimate3-phosphate synthase (EPSPs), which acts fundamentally in the pathway of shikimic acid. Since this is an explorer of formidable secondary metabolites of the plant, through the inhibition of this enzyme glyphosate obstructs the production of these compounds, causing a metabolic imbalance (YAMADA and Castro, 2007). It is necessary to highlight that glyphosate is indicated for the control of invasive monocotyledonous and dicotyledonous herbs, in cultures such as: rice, plum, banana, sugar cane, coffee, citrus, tobacco, apple, corn, pasture, soy, grape and sugar cane, cocoa, nectarine, pear, peach, rubber and no-till cotton (AMARANTE JÚNIOR and Santos, 2002), being the most used in Brazil and world.

The herbicide Cletodim acts as an ACCase inhibitor, which belongs to the group of Cyclohexanediones, being used for the control of post-emergence grasses, acting as a selective product for dicot crops (MONTEIRO et al., 2017), in addition to said Clethodim inhibits the 
International Journal of Agriculture and Environmental Research

ISSN: 2455-6939

Volume: 06, Issue: 06 "November-December 2020"

synthesis of lipids, acting in mono and dicotyledonia achieving good control results in isolation, in mixture or in sequential application (LICORINI et al., 2015), causing paralysis of the plant's growth system, affecting the meristem and the consequent death of the plant in a few weeks.

According to Stephenson et al. (2006) the herbicide Haloxifope-P-methyl belonging to the chemical group aryloxyphenoxypropionic acid, inhibits the synthesis of lipids, or ACCase inhibitors, in this way if the production of lipids does not occur, there is no production of cell membranes and plant growth is halted.

Fluazifope-P-butyl, an herbicide belonging to the chemical families aryloxyphenoxypropionates and cyclohexanediones, inhibits the enzymes acetyl CoA-carboxylase (ACCase), being the first biosynthetic enzyme of fatty acids. ACCase catalyzes the carboxylation of acetyl-CoA, being dependent on ATP to form malonyl-CoA, which is also used in lipid elongation and synthesis of secondary metabolites (SASAKI and NAGANO, 2004).

Thus, the study aimed to evaluate the efficiency of different herbicides in controlling Digitaria insularis in coffee crops.

\section{MATERIAL AND METHODS}

The survey was carried out from 09/04/2020 to 05/09/2020 at the Serrinha site, municipality of Campestre, South of Minas Gerais, located at the geographical coordinates Latitude 21 ${ }^{\circ} 43^{\prime} 43^{\prime \prime} \mathrm{S}$ and Longitude $46^{\circ} 16^{\prime} 44^{\prime \prime} \mathrm{W}$, with an attitude of 1.290 meters. The predominant climate is oceanic. (Climate-data.org, 2020).

The selected area was an Arabica coffee plantar cultivar Catuai Vermelho 144 in production, with 4 years, spacing of $3,2 \mathrm{~m}$ by $1,0 \mathrm{~m}$, totaling $3,125 \mathrm{plants} / \mathrm{ha}^{-1}$.

The experimental plots were composed of $1 \mathrm{~m}^{2}$ between the lines of the coffee tree, where they were with an average of 100 plants of Digitaria isularis per m2, with an average height of $10 \mathrm{~cm}$, in the initial vegetative stage.

The treatments were: Roundup Original (Glyphosate $445 \mathrm{~g} / \mathrm{L}-5 \mathrm{~L} / \mathrm{ha}^{-1}$ ), Select (Cletodim 240 $\mathrm{g} / \mathrm{L}+$ vegetable oil $930 \mathrm{~g} / \mathrm{L}$ - according to package insert specification $\left.-0,5 \mathrm{~L} / \mathrm{ha}^{-1}+1 \mathrm{~L} / \mathrm{ha}^{-1}\right)$, Verdict R (Haloxifope-P-methyl 124,7 g/L + vegetable oil $930 \mathrm{~g} / \mathrm{L}$ - according to package insert specification $-0,5 \mathrm{~L} / \mathrm{ha}^{-1}+1 \mathrm{~L} / \mathrm{ha}^{-1}$ ), Fusilade (Fluazifope-P-butyl $250 \mathrm{~g} / \mathrm{L}-0,75 \mathrm{~L} / \mathrm{ha}^{-1}$ ) and control (without adding herbicide).

The application was carried out with a backpack sprayer, volume of $100 \mathrm{~L}$ of syrup/ha- ${ }^{-1}$, type Teejet 11002. 
International Journal of Agriculture and Environmental Research

ISSN: 2455-6939

Volume: 06, Issue: 06 "November-December 2020"

The evaluation of the percentage of death of Digitaria insularis L. was performed visually, according to the methodology adopted by the EWRC (1964), where 0\% is absence of death and $100 \%$ complete death of the plant (VILELA et al., 2004), and the first evaluation was performed at 7 days after application, the second was performed at 15 days and the last evaluation was performed at 30 days after application.

Plagiotropic branches were also marked in the middle third of the coffee plants, to assess the number of internodes developed at 90 days after herbicide application. (ALFONSI, 2008), in addition to the visual analysis of toxicity.

According to (MAGALHÃES et al., 2012) the toxicity caused by herbicides to coffee was evaluated at 7,15, 30,45, 60 and 90 days after application (DAA), by assigning phytotoxicity percentage scores in relation to to the control (without application), with zero absence of symptoms and 100, complete senescence of the plant.

The chosen design was randomized blocks, consisting of 5 treatments with 4 replications, totaling 20 experimental plots.

The surveyed results were subjected to analysis of variance and the comparison of the averages made by the Scott-Knott test, at $5 \%$ probability, both using the SISVAR ${ }^{\circledR}$ software (FERREIRA, 2014).

\section{RESULTS AND DISCUSSION}

The results obtained after the application of the herbicides at 7, 15 and 30 days after application (Table 1), where the average percentage values of death of Digitaria insularis L. are described, according to the methodology adopted by EWRC (1964).

Table 1: Average percentage of death of Digitaria insularis $\mathbf{L}$.

7, 15 and 30 days after herbicide application.

\begin{tabular}{lrrr}
\hline TREATMENTS & 7 DAA & 15 DAA & 30 DAA* \\
\hline Glyphosate & $52,0 \mathrm{~A}$ & $45,0 \mathrm{~B}$ & $35,0 \mathrm{C}$ \\
Cletodim & $55,0 \mathrm{~A}$ & $70,0 \mathrm{~A}$ & $85,0 \mathrm{~A}$ \\
Haloxifop-P-methyl & $40,0 \mathrm{~B}$ & $70,0 \mathrm{~A}$ & $84,0 \mathrm{~A}$ \\
Fluazifop-P-butyl & $20,0 \mathrm{C}$ & $35,0 \mathrm{~B}$ & $58,0 \mathrm{~B}$ \\
Control & $0,00 \mathrm{D}$ & $0,00 \mathrm{D}$ & $0,00 \mathrm{D}$ \\
\hline
\end{tabular}

Different letters in the column, differ statistically by the Scott-Knott test, at $5 \%$ probability. *DAA (day after application). 
International Journal of Agriculture and Environmental Research

ISSN: 2455-6939

Volume: 06, Issue: 06 "November-December 2020"

In analyzing the effects of herbicides in relation to the control of Digitaria insularis, at 7 days after application of the herbicides, the treatment that showed the best statistical results in relation to the control were Cletodim $240 \mathrm{~g} / \mathrm{L}$ (Select) with the use of vegetable oil and Glyphosate $445 \mathrm{~g} / \mathrm{L}$ (Original Roundup).

According to Moreira et al. (2007) Glyphosate control was better at 7 DAA, with a reduction in efficiency at 15 and $30 \mathrm{DAA}$, due to plant recovery.

At 15 DAA of the herbicides, Cletodim $240 \mathrm{~g} / \mathrm{L}$ (Select) and Haloxifope-P-methyl 124,7 g/L (Verdict R) presented the best results in relation to weed death (Digitaria insularis L.), both recommended in the package insert use associated with vegetable oil.

Jordan et al. (1996) tested the influence of adjuvants on the effectiveness of Cletodim $240 \mathrm{~g} / \mathrm{L}$, in the control of weeds (Digitaria insularis L.) in different species of chemicals. The result shows a greater level of control when associated with oily adjuvants.

At 30 DAA the herbicides Cletodim $240 \mathrm{~g} / \mathrm{L}$ (Select) and Haloxifope-P-methyl 124,7 g/L (Verdict R) showed that they obtained efficiency in the control of Digitaria insularis L. with Fluazifope-P-butyl $250 \mathrm{~g} / \mathrm{L}$ (Fusilade) having an improvement in efficiency but was not able to do the control.

The use of a single mechanism of action to control Digitaria insularis in areas where glyphosate resistance already occurs can result in a selection pressure source for resistance to ACCaseinhibiting herbicides (GEMELLI et al., 2012).

Adegas et al. (2010) using the herbicides Clethodim, Fluazifope-P-buthyl, Tepraloxydim, haloxyfope-methyl and Paraquat, obtained controls above 90\%. However, when the plant grows, it sprouts, and this control drops to an average of 50\%, confirming that the control of perennial plants is more difficult (FORNAROLLI et al., 2011).

It presents positive results of the herbicides used as Cletodim and Haloxifope-P-butylíco, controlling Digitaria insularis L. and with an improvement 30 DAA of Fluazifope-P-methylíco.

Still, for the Ministry of Agriculture, Livestock and Supply (MAPA, 2018) the average control that a herbicide must promote to be considered viable and request a registration with the mentioned agency is $80 \%$. Thus, from the treatments used, it is concluded that all are effective, with the exception of the use of Glyphosate isolated in the management of resistant plants of Digitaria insularis, however the control must be done in early stages of plant development.

Glyphosate is a post-emergent herbicide that acts on the blockade of the enzyme enolpiruvilshikimato-phosphate (EPSP), which is responsible for the synthesis of aromatic amino acids 
(tyrosine, tryptophan and phenylalanine), which perform several functions in the plant. Blocking EPSP synthesis generates shikimate accumulation and loss of amino acids responsible for proteins essential for plant growth. The symptoms caused from the third to the fifth day after application are visible. (MARCHI et al., 2008).

The herbicides Cletodim, Haloxifope-P-methylíque and Fluazifope-P-butilíco are responsible for the first reaction in the metabolic route of lipid synthesis involving the paralysis of the enzyme Acetyl-CoA carboxylase (ACCase), which is responsible for the components of phospholipids and triacylglycerols that combined form double lipid layers that serve as a cell membrane. The paralysis of the ACCase enzyme interrupts the formation of new cell membranes, and without new cell membranes the growth of the plant is paralyzed.

The symptoms take several days after the treatment to be evident, but the plants stop their growth right after the application of the herbicide. (MARCHI et al., 2008).

Table 2: Average number of internodes developed at 90 DAA.

\begin{tabular}{lc}
\hline \multicolumn{1}{c}{ TREATMENTS } & $\begin{array}{c}\text { NUMBER OF INTERNATIONALS } \\
\text { DEVELOPED }\end{array}$ \\
\hline Glyphosate & $3 \mathrm{C}$ \\
Cletodim & $5 \mathrm{~A}$ \\
Haloxifop-P-methyl & $5 \mathrm{~A}$ \\
Fluazifop-P-butyl & $4 \mathrm{~B}$ \\
Control & $3 \mathrm{C}$ \\
\hline Different letters in the column, differ statistically by the Scott-Knott test, at 5\% probability.
\end{tabular}

There were statistical differences between treatments $\mathrm{A}, \mathrm{B}, \mathrm{C}$ in relation to the number of internodes developed, thus showing the importance of making the correct management of the control of Digitaria insularis L. being observed a difference in the growth of the plant in the plots referring to Glyphosate and to the witnesses, where Digitaria insularis L. was not controlled (Table 2). No leaves with signs of intoxication were found in the plagiotropic branches of the coffee tree, thus obtaining positive results regarding the use of herbicides in the chemical control of weeds, highlighting that the control plots met $100 \%$ of live digitalis plants, competing in water, light and nutrients with the coffee tree.

Coffee plants grow slowly when they are associated with weeds, allowing them to make better use of the available resources than the crop. The interference imposed by these plants results in a decrease in the nutrient content in the leaves (RONCHI et al., 2003), less growth (RONCHI and Silva, 2006), and, consequently, less coffee production. 
International Journal of Agriculture and Environmental Research

ISSN: 2455-6939

Volume: 06, Issue: 06 "November-December 2020"

According to the results, there were no signs of toxicity in low leaves of the plagiotropic branches of the coffee tree caused by the use of herbicides.

\section{CONCLUSION}

It is concluded that the use of Cletodim $240 \mathrm{~g} / \mathrm{L}$ (Select) and Haloxifope-P-butyl 124,7 $\mathrm{g} / \mathrm{L}$ (Verdict R), associated with vegetable oil $930 \mathrm{~g} / \mathrm{L}$ in the dosage of $0,5 \%$ of the syrup, were the best treatments among those used in this research to control Digitaria insularis L. in coffee plantation, after 30 days of application, and in relation to the development of plagiotropic branches, we can highlight that the inefficient control of bittergrass plants, affected the development of plagiotropic branches.

\section{REFERENCES}

ADEGAS, F. S. et al. 2010. Alternativas de controle químico de Digitaria insularis resistente ao herbicida glyphosate. In: CONGRESSO BRASILEIRO DA CIÊNCIA DAS PLANTAS DANINHAS, 2010, Ribeirão Preto. Resumos... Ribeirão Preto: Sociedade Brasileira da Ciência das Plantas Daninhas.

ALFONSI, E. L. 2008. Uso de índices fenológicos em modelos de previsão de produtividade do cafeeiro. 2008. 104 f. Tese (Doutorado em Fitotecnia) - Escola Superior de Agricultura Luiz de Queiroz, Piracicaba. Available in: <http://www.sbicafe.ufv.br/handle/123456789/9039>. Access in: 16 Jun. 2020.

AMARANTE JUNIOR, O. P., SANTOS, T. C. R. 2002. Glifosato: propriedades, toxicidade, usos e legislação. Química Nova, 25(4), 589-593. Available in: $<$ https://www.scielo.br/scielo.php?pid=S010040422002000400014\&script=sci_abstract\&tlng=pt>. Acesso em: 28 Oct. 2020.

CliMATE-DATA.ORG. 2020. Clima: Nova Crixás. Available in: <http:// pt.climatedata.org/location/43194/>. Access in: 20 Oct. 2020.

COMPANHIA NACIONAL DE ABASTECIMENTO (CONAB). 2019. Acompanhamento da safra brasileira de café: safra 2019: segundo levantamento, maio 2019.Brasília, 5(2), 161. Available in: <https://www.conab.gov.br/info-agro/safras〉. Access in: 23 Oct. 2020.

EUROPEAN WEED RESEARCH COUNCIL - EWRC (1964). Report of the 3th and 4th meetings of EWRC- Comittee of methods in weed research. Weed Res., 4(1), 88.

FAPEMIG. 2018. A produção de café em Minas Gerais: desafios para a industrialização. Fundação João Pinheiro, Diretoria de Estatística e Informações. - Belo Horizonte: FJP. 
International Journal of Agriculture and Environmental Research

ISSN: 2455-6939

Volume: 06, Issue: 06 "November-December 2020"

FERREIRA, D. F. 2014. Sisvar: um guia dos seus procedimentos de comparações múltiplas Bootstrap. Ciência e Agrotecnologia, 38(2), 109-112.

FIALHO, C. M. T., FRANÇA, A. C., TIRONI, S. P., RONCHI, C. P., SILVA, A. A. D. 2011. Interferência de plantas daninhas sobre o crescimento inicial de Coffea arábica. Planta Daninha, Viçosa-MG, 29(1), 137-147.

FORNAROLLI, D. A. et al. 2011. Manejo de biótipos de Digitaria insularis resistente ao herbicida glifosato. In: III SIMPÓSIO INTERNACIONAL SOBRE GLYPHOSATE: Uso Sustentável, 3., Botucatu. Anais... Botucatu, p. 317320.

GEMELLI, A., Oliveira Jr., R. S., Constantin, J., Braz, G. B. P., Jumes, T. M. C., Oliveira Neto, A. M., Dan, H. A., Biffe, D. F. 2012. Aspectos da biologia de Digitaria insularis resistente ao glyphosate e implicações para o seu controle. Revista Brasileira de Herbicidas, 11(2), 231-240.

IBGE (2016) - Sidra - Agricultura. Instituto Brasileiro de Geografia e Estatística. [cit. 2016-1004]. Available in: <https://sidra.ibge.gov.br/home/pimpfrg/nordeste>. Access in: 09 de Oct. 2020.

JORDAN, D. L., VIDRINE, P. R., GRIFFIN, J. L., REYNOLDS, D. B. 1996. Influence of adjuvants on efficacy of clethodim. Weed Technology, 10(4), 738-743. Available in: <https://doi.org/10.1017/S0890037X00040744>. Access in: 14 Oct. 2020.

KISSMANN, K. G., GROTH, D. 1997. Plantas infestantes e nocivas. 2.ed. São Paulo: BASF, 825 in:< https://www.bdpa.cnptia.embrapa.br/consulta/busca? $\mathrm{b}=\mathrm{ad} \&$ biblioteca=CNPSO\&busca $=\mathrm{a}$ utoria:\%22KISSMANN,\%20K.G.\%22>. Access in: 16 Ago 2020.

LICORINI, L. R. et al. 2015. Identificação e controle de biótipos resistentes de Digitaria insularis (L.) Fedde ao glyphosate. Revista Brasileira de Herbicidas, Londrina, PR, 14(2), $148-154$

LORENZI, H. 2014. Manual de Identificação e Controle de Plantas Daninhas: plantio direto e convencional. 7.ed. Nova Odessa: Plantarum, 384p.

MAGALHÃES, C.E.O. et al. 2012. Seletividade e controle de plantas daninhas com oxyfluorfen e sulfentrazone na implantação de lavoura de café. Planta daninha, Viçosa, 30(3), 607616. Available in: <https://www.scielo.br/scielo.php?script=sci_arttext\&pid=S010083582012000300017\&lng=pt\&tlng=pt >. Access in: 03 Dec. 2020. 
International Journal of Agriculture and Environmental Research

ISSN: 2455-6939

Volume: 06, Issue: 06 "November-December 2020"

MAPA (2018) - Ministério da agricultura Pecuária e Abastecimento - AGROFIT Sistemas de Agrotóxicos Fitossanitários. Available in: $\langle$ http://agrofit.agricultura.gov.br/agrofit_cons/principal_agrofit_cons $>$. Access in: 15 Jun. 2020.

MARCHI, et. al. 2008. HERBICIDAS: MECANISMO DE AÇÃO E USOS. Embrapa, Documento, 227. Available in: <https://www.infoteca.cnptia.embrapa.br/bitstream/doc/571939/1/doc227.pdf>. Access in: 05 Dec. 2020.

MDIC. 2016 - Sistema de Análise das Informações de Comércio Exterior. Ministério do Desenvolvimento, Indústria e Comércio Exterior. [cit. 2016-10-04]. Available in: <http://aliceweb.mdic.gov.br/>. Access in: 09 de Dec. 2020.

MONTEIRO, L.O. et al. 2017. Eficácia do herbicida cletodim em mistura com bioestimulante a base algas no controle do milho rr. Revista Agroveterinária, Negócios e Tecnologia, Coromandel, 2(1), 08-22.

MOREIRA, M. S. et al. 2007. Resistência de Conyza canadensis e Conyza bonariensis ao herbicida glyphosate. Planta Daninha, Viçosa, 25(1), 157-164.

RONCHI, C. P. et al. 2003. Acúmulo de nutrientes pelo cafeeiro sob interferência de plantas daninhas. Planta Daninha, 21(2), 219-227. Available in: <https://www.researchgate.net/publication/250031460_Acumulo_de_nutrientes_pelo_caf eeiro_sob_interferencia_de_plantas_daninhas>. Access in: 24 Nov. 2020.

RONCHI, C. P., SILVA, A. A. 2006. Effects of weed species competition on the growth of young coffee plants. Planta Daninha, 24(2), 415-423. Available in: <https://www.researchgate.net/publication/250031848_Effects_of_weed_species_compet ition_on_the_growth_of_young_coffee_plants>. Access in: 24 Nov. 2020.

SASAKI, Y., NAGANO, Y. 2004. Plant acetyl-CoA carboxylase: structure, biosynthesis, regulation, and gene manipulation for plant breeding. Bioscience, Biotechnology and Biochemistry, 68, 1175- $1184 . \quad$ Available in: <https://www.tandfonline.com/doi/abs/10.1271/bbb.68.1175\#aHR0cHM6Ly93d3cudGFu ZGZvbmxpbmUuY29tL2RvaS9wZGYvMTAuMTI3MS9iYmIuNjguMTE3NT9uZWVk QWNjZXNzPXRydWVAQEAw>. Access in: 15 Jun. 2020. 
International Journal of Agriculture and Environmental Research

ISSN: 2455-6939

Volume: 06, Issue: 06 "November-December 2020"

STEPHENSON, G. R., FERRIS, I. G., HOLLAND, P. T., NORDBERG, M. 2006. Glossary of terms relating to pesticides (IUPAC Recommendations 2006). Pure and Applied Chemistry, 78(11), 2075-2154.

VILELA et al. 2004. Avaliação da eficiência de herbicidas no controle de plantas daninhas em alfafa. Ciência. Agrotecnologia., Lavras, 28(4), 729 - 735.

YAMADA, T., CASTRO, P. 2007. Efeito do glifosato nas plantas: implicações fisiológicas e agronômicas. International Plant Nutrition Institute (IPNI). Encarte Técnico, n. 119. Available in:

$<\mathrm{http}: / /$ www.ipni.net/publication/iabrasil.nsf/0/737CD8A86525A2EC83257AA1005FE1B9/\$FILE/Encarte-119.pdf $>$. Access in : 28 Oct. 2020. 